\title{
Reference GNSS Stations for Warning on Possibility of Upcoming Earthquake in Zagreb
}

\author{
Nikola Solaric $^{1, ~ *}$, Miljenko Solaric ${ }^{1}$, Marijan Marjanovic ${ }^{2}$, Zlatko Bogdanovski $^{3}$, Sasho Dimeski $^{4}$ \\ ${ }^{1}$ Institute for Geomatics, Faculty of Geodesy, University of Zagreb, Zagreb, Croatia \\ ${ }^{2}$ The State Geodetic Survey, The State Geodetic Administration, Zagreb, Croatia \\ ${ }^{3}$ Department of Geodesy and Mathematics/ Faculty of Civil Engineering, Ss. Cyril and Methodius University in Skopje, Skopje, North \\ Macedonia \\ ${ }^{4}$ Agency for Real Estate, Skopje, North Macedonia
}

\section{Email address:}

nsolaric@geof.hr (N. Solaric), miljenko.solaric@geof.hr (M. Solaric), info $a$ dgu.hr (M. Marjanovic),

zlatkobog@gmail.com (Z. Bogdanovski), dimeski $@$ katastar.gov.mk (S. Dimeski)

${ }^{*}$ Corresponding author

\section{To cite this article:}

Nikola Solaric, Miljenko Solaric, Marijan Marjanovic, Zlatko Bogdanovski, Sasho Dimeski. Reference GNSS Stations for Warning on Possibility of Upcoming Earthquake in Zagreb. Earth Sciences. Vol. 9, No. 3, 2020, pp. 100-107. doi: 10.11648/j.earth.20200903.12

Received: March 9, 2020; Accepted: April 9, 2020; Published: May 18, 2020

\begin{abstract}
Distances between permanent GNSSS stations in positional systems are usually short between $30 \mathrm{~km}$ and $80 \mathrm{~km}$. So calculated distances between the GNSS stations from their position coordinates calculated by processing collected GNSS data with Bernese software will be very well determined. The first time we determined that two days before earthquake in Kraljevo 2010 were shortening of sides between the GNSS referent stations, that this was a compression of the Earth's crust two days before the earthquake. This effect was also confirmed on the Earthquakes Dreznica 2013, Skopje 2016 and Zagreb 2018 and that after compression two or several days after the earthquake occurs. However, they can also enable geophysicists to determine warn of possible earthquakes. On the end it was suggested that in the Control Center of CROPOS is required to establish a department for determination of compression in Earth crust based on GNSS measurement of the reference GNSS stations. This compression is possible to determine by "The method of daily changing the distance between GNSS permanent referent stations". After determination compression in Earth crust and using other geophysical methods will be probably possible to warn to upcoming earthquakes.
\end{abstract}

Keywords: GNSS, AGROS, MAKPOS, CROPOS, Earthquake

\section{Introduction}

The permanent reference GNSS $^{1}$ stations of positioning systems are used by geodesists for precisely determination the position of the points on Earth using the GNSS satellites. However, they can also enable geophysicists to determine displacements of the Earth's crust and warn of possible earthquakes.

Distances between the reference GNSS stations are generally between 30 and $80 \mathrm{~km}$. At such relatively small distances between the reference GNSS stations in comparison with the distances of the GNSS satellites from

1 GNSS - abbreviation of Global Navigation Satellite Systems. the Earth's surface, measurement error caused by the troposphere and the ionosphere (not covered by the corrections) will be virtually the same.

Thus, the calculated distances between the GNSS stations from their position coordinates calculated by processing collected GNSS data with the Bernese software will be very well defined.

This method can be called "The method of daily changing the distance between GNSS permanent referent stations". We applied it to the analysis of the distances between the permanent reference GNSS stations before the earthquake, during time of earthquakes and after earthquake when were 
earthquakes:

a) 2010 at Kraljevo (Serbia),

b) 2013 at Dreznica (near Senj) in Croatia and

c) 2016 in Skopje (Macedonia).

In these three cases just before earthquake two to three days were the compression of the Earth's crust, i.e. there were a shortening of the distances between GNSS stations near the epicenter of the earthquake.

We need to underline that for geophysical research it should special attentions has to be paid to the stability of referent GNSS stations.

\section{The Analysis of the Deformation of the Earth's Crust}

\subsection{The Earthquake in Surroundings of Kraljevo 3.11.2010 (Serbia)}

The earthquakes in surroundings of Kraljevo in Serbia were on 3.11.2010. This biggest earthquake was a moderate earthquake with a magnitude of 5.4 degrees on the Richter scale. The hypocentre of the earthquake was at a depth of 10 $\mathrm{km}$, and it was felt throughout Serbia, Macedonia, Bosnia and Herzegovina and partially in Croatia.

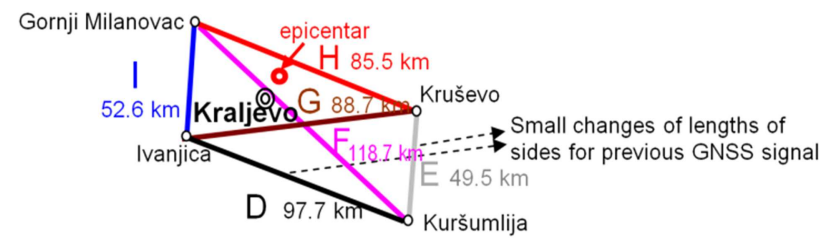

Figure 1. Nearly all distances were slightly decreased two days before the earthquake, while the sides ( $E$ and $D$ in the quadrilateral) which were far from the epicenter of earthquakes did not show daily change of distance. [12]

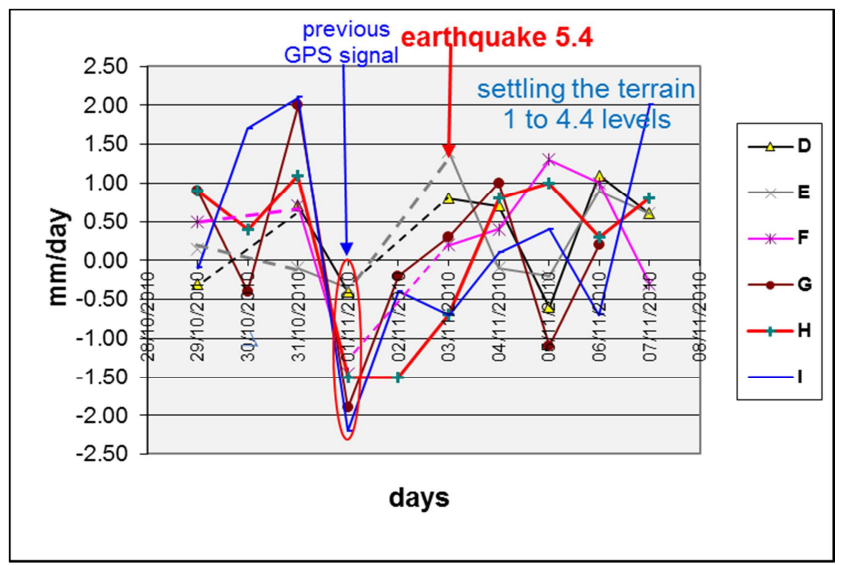

Figure 2. Graph of daily changes of the distances between the AGROS permanent referent GNSS stations presented in quadrangle with diagonals around Kraljevo.

In that time, the $\mathrm{AGROS}^{2}$ GNSS positioning system was already established in Serbia. In the paper [1] the 24-hour

2 AGROS - abbreviation of Active Geodetic Referent Network (Osnova) of Serbia. This is GNSS positioning system of Serbia and has more than 30 referents permanent GNSS stations. coordinates of GNSS referent stations calculated by using the Bernese software and the distances between the AGROS GNSS reference stations are presented: Krusevo, Gornji Milanovac, Ivanjica and Kursumlija around Kraljevo (Figure 1). Thus, it was possible to draw a graph of the daily change of distance between neighboring referent GNSS stations at (Figure 2). From this graph, the first time we discovered that two days before the earthquake near its epicenter there was a shortening of distances between neighboring GNSS stations, i.e. the compression of the Earth's crust occurred. Compression of the Earth's crust is previous GNSS signal before earthquake. [12]

\subsection{The Earthquake at Dreznica (Near Senj) 2013 (Croatia)}

In 2008, the Croatian GNSS positioning system CROPOS ${ }^{3}$ was established for precise positioning and deformation calculation of the Earth's crust. [3, 7]

In Croatia was a small earthquake on 30.07.2013 at 14:58 with an epicentre at Dreznica, $15 \mathrm{~km}$ north-east of Senj. [13, 15] The earthquake's magnitude was 4.6 on the Richter scale and its hypocentre was at a depth of $20 \mathrm{~km}$. The intensity in the earthquake epicentre was VI-VII on the MercalliCancani-Sielberg (MCS) scale.

The earthquake was felt in the areas of Ogulin, Karlovac and Zagreb, as well as in southern and central Slovenia. The telephone 112 of information centre in Karlovac received in [15] only two reports of damage. Given the small earthquake intensity, only minor material damage was possible in the epicentre area.

After analysis of daily changes of distances between all four CROPOS stations around Dreznica, we have found that the daily changes of distances between the CROPOS stations were very small (Figure 3 ). However, two days before the earthquake all sides of the quadrangle were slightly decreased (compressed). There were practically no changes at the sides that are further away from the earthquake's epicentre, as was the case on the sides Karlovac-Slunj and Karlovac-Rijeka (Figure 4).

Taking into consideration such small changes of distances and measurements errors in the case of small earthquakes, we cannot predict an earthquake for certain. However, two days before the earthquake there were a decrease of distances between the GNSS referent stations (the terrain was compressed), similar to the earthquake in Kraljevo on 03.11.2010.

However, the Kraljevo earthquake was larger (moderate earthquake) with a magnitude of 5.4 on the Richter scale and the daily changes of distances were slightly larger. Therefore, it is necessary to investigate whether such a phenomenon occurs in major earthquakes too. [13]

Given the small changes in distance between the reference stations and taking into consideration the measurement errors in such small earthquakes, it would not be possible to predict an earthquake with certainty in advance. However, the

3 CROPOS - abbreviation of Croatian Positional System. This positional system has 33 permanent GNSS stations. 
situation in Dreznica also shows those two days before the earthquake there was a decrease of distances between the reference GNSS stations, i.e. this was Earth crust "compression", to that of the earthquake in Kraljevo on 03.11.2010. This time period from "compression" to stretching, i.e. fracture - earthquake could be after as long as two days, or even something longer.

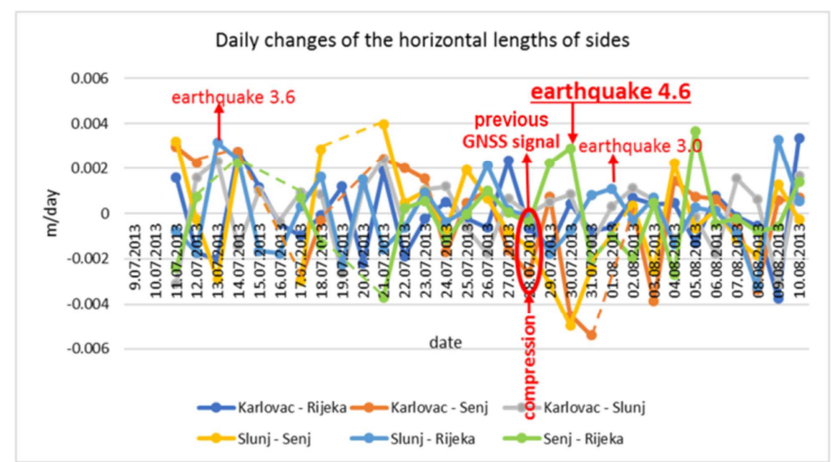

Figure 3. The daily changes of horizontal distances between the CROPOS stations near Dreznica on 28.07.2013 were small. However, it can be concluded those two days before the earthquake that all the sides of the quadrangle near the epicentre were slightly decreased (compressed). (Some parts of the Senj station side are marked with an interrupted line, indicating that measurements on some days are not registered). [13]

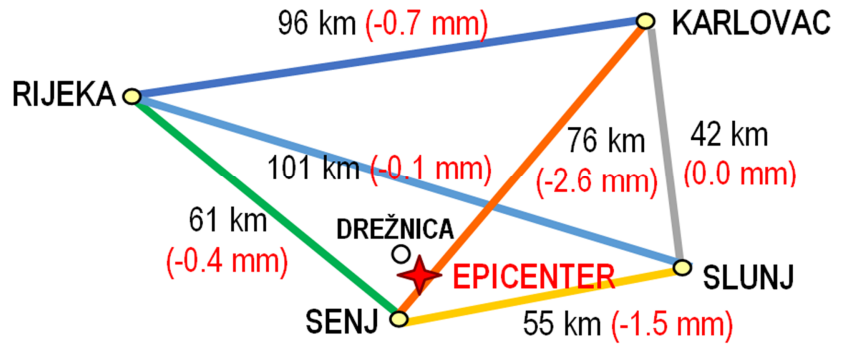

Figure 4. Compressions of sides and diagonals between CROPOS stations near Dreznica 28.07.2013.

\subsection{The Earthquake in Skopje in 2016 (North Macedonia)}

In order to carry out the analysis of the earth's deformations before and after the earthquakes in Skopje in September 2016, we chose distances between four neighboring MAKPOS ${ }^{4}$ permanent GNSS reference stations near epicenter of the earthquake 2016: Skopje, Kumanovo, Veles and Tetovo. Few smaller earthquakes and the biggest earthquake of magnitude 5.2 degrees per Richter happened at 15:10 (local time) on 11.09.2016 in the vicinity of Skopje. The earthquake's epicentre was located at geographic latitude $\varphi=41.98^{\circ}$ and geographic longitude $\lambda=21.50^{\circ}$ and its hypocenter was at a depth of $4 \mathrm{~km}$. It was felt in Kosovska Mitrovica, Nis, Vranje and Belgrade. [16]

In order to get an overview of changes of all distances between 4 MAKPOS GNSS stations, in Figure 5 are shown graphically all daily changes of distances between stations. In that way we determined the deformations of Earth's crust on the surface as the pressure in it. The criterion for

4 MAKPOS abbreviation of MACedonian POsitional System have 14 referents permanent GNSS stations. definition when is compression in Earth's crust for our network type may be that all distances between GNSS stations are shorted. However, a site may appear that does not have a shortcut, if it was later earthquake on big distance from that site.

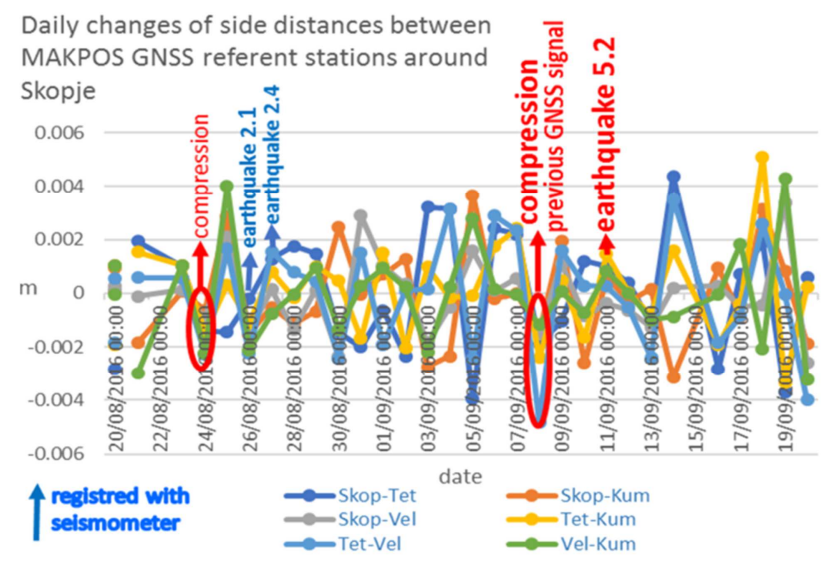

Figure 5. Daily changes distances between the observed MAKPOS GNSS referent stations around Skopje. The decrease in all the distances (terrain "compression") occurred on 08.09.2016 and three days later the strongest earthquake in this area occurred. [14]

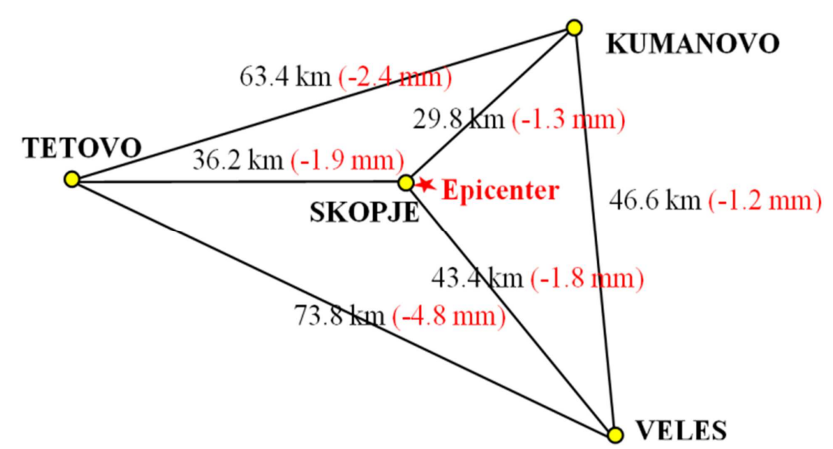

Figure 6. GNSS reference stations of the MAKPOS network and determination shift of the Earth's crust before and after the earthquake in Skopje in 2016 in [14]. The distances between the observed GNSS stations in the MAKPOS network near Skopje and in the red bracket it was labeled how are shorted the distances of 08.09.2016 compared to 20.08.2016.

It is interesting to mention, as it can be seen from Figure 6, that on 08.09.2016 all the distances between the observed MAKPOS GNSS referent stations decreased. We shall call the decrease in distances between the MAKPOS stations as "compression". This means that three days before the earthquake in Skopje there was a "compression" (i.e. decrease in the side distances between points on the Earth's crust) around Skopje (Figure 6).

We also outlined a graph of the total horizontal length changes between the MAKPOS GNSS stations from 20.08.2016 to 20.09.2016 in Figure 7. Based on the graph, it can be seen that in this time period of about 30 days the site Skopje-Tetovo was enlarged to a maximum of about $6 \mathrm{~mm}$, Tetovo-Kumanovo $4 \mathrm{~mm}$ and Tetovo-Veles $2 \mathrm{~mm}$. The other three sides had much shorter contractions. This means that the Earth's crust west of Skopje pushed the Earth's crust of east of Skopje. 


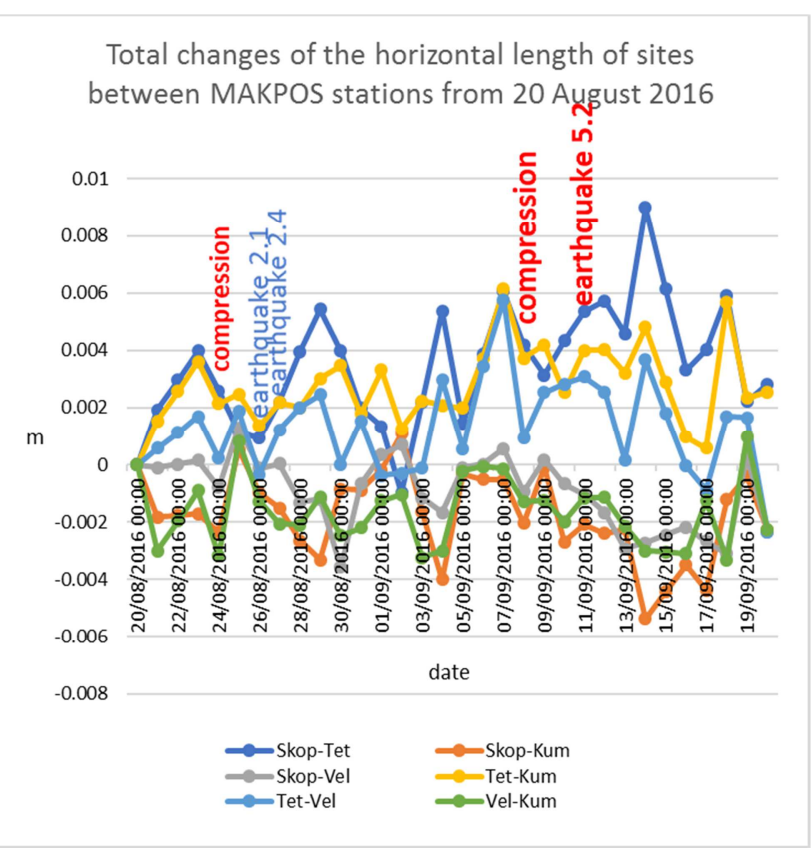

Figure 7. Display of total changes of horizontal distances between the MAKPOS GNSS= stations near Skopje from 20.8.2016 to 20.9.2016. [14]

Subsequently, we decided to do analysis and graphically display the changes of the 24-hour distances between GNSS reference stations over a longer period of time. Thus, in the paper [14], the graphs of these changes were plotted for each month from 1.1.2016 to 30.10.2016. In this period of about 8 months before the biggest earthquake occurred there were several smaller compressions after which it was more earthquakes. Only after two minor compressions, there ware no earthquakes in the list of all earthquakes registered in the EMSC (European-Mediterranean Seismic Center). But this does not mean that they did not happen.

\section{Geology of Zagreb and Environment}

In Zagreb and its surroundings was a great earthquake in 1860. Its magnitude was 6.3 degrees per Richter and its intensity in epicenter in Kasina was VIII by the Mercalli Cancani - Sielberg scale.

If this kind of earthquake occurred today with a magnitude of 6.3 degree per Richter scale, about 3000 people would be killed, another 100,000 people would be injured, and 22 percent of the residential area would be destroyed. [10], [19]. Prof. M. Oluic "wrote that a devastating earthquake in Zagreb will happen again probably from Medvednica". [5, 6].

The City of Zagreb is located at the contact of large tectonic plates: in the northwest of the Alps and in the east and in the south of the Dinarides.

The causes of earthquakes are tectonic movements occurring in the regional space. Due to the leaning and/or undercutting of certain tectonic plates, one under another lithosphere cracks and clefts (fault) become the seismic sources of earthquakes. In the wider area of Zagreb there are 7 known seismic sources: Medvednica, Zagreb, Pokupsko, Bilogora, Kalnik, Ivančica and Metlika seismic source. [4]
He wider area of Zagreb is seism-tectonically very active, and this is the reason for the crossing and the confrontation of major faults (Figure 8 and Figure 9).

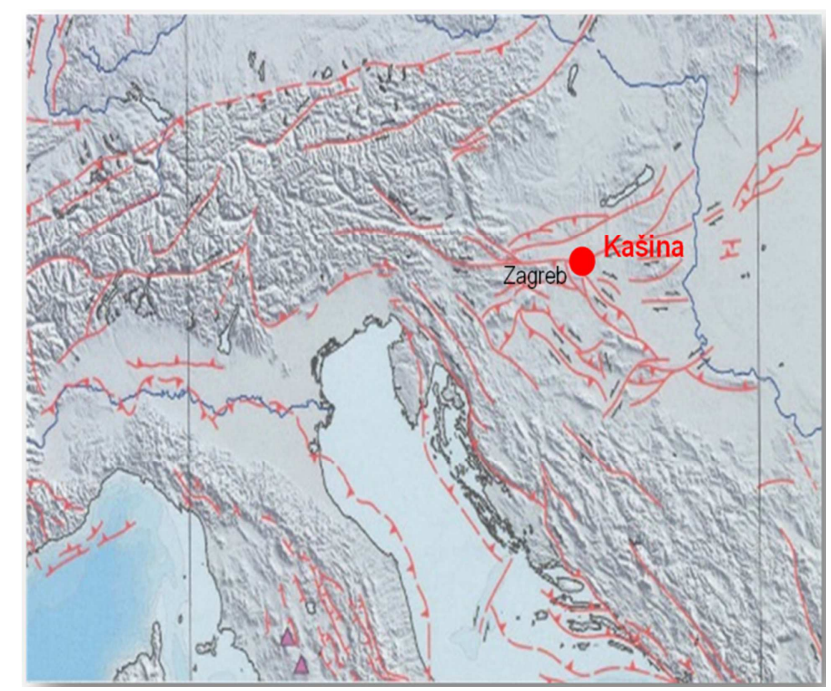

Figure 8. The faults in the great area around Zagreb. [4]

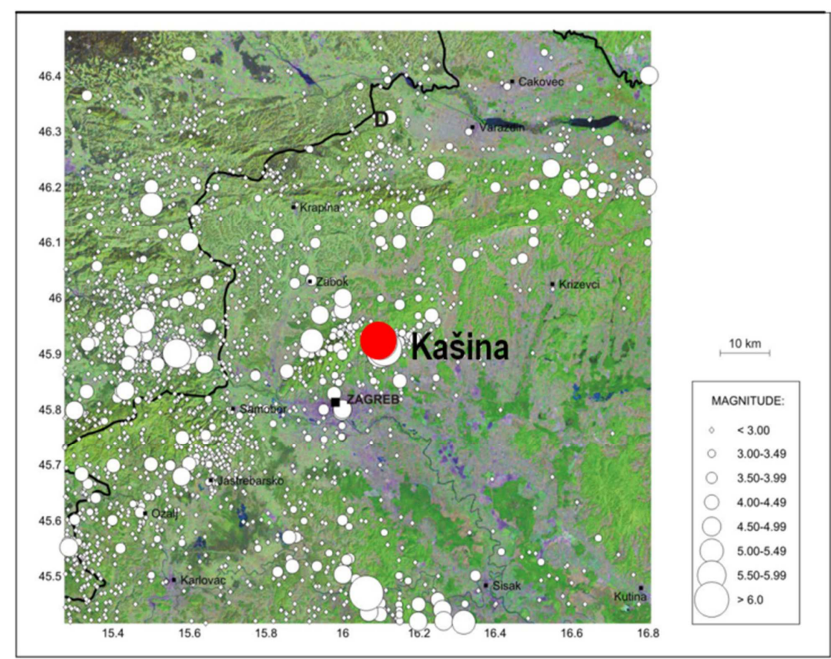

Figure 9. The epicenters of the earthquakes in wide area around Zagreb in time period 1880-2004. The epicenter of the earthquake in Kasina from 1880 is marked with red color. [4]

The earthquakes in Zagreb are most commonly occurring in the Kasina and Stubica fault. One fault goes along Medvednica from the Zagorje side and stretches down to Medvednica. The other earthquakes defect goes perpendicular to him, roughly through Kasina. Professor Marijan Herak pointed out and added that there are a number of defects extending from Brezica to Stubica. These failures may cause earthquakes of magnitude greater than 6 by Richter. It should be remembered that the western parts of Zagreb are more vulnerable to Brezice earthquake - than from Kasina earthquake. He stressed that seismic maps throughout Croatia were completed, which one of conditions for application European building regulations.

Interdisciplinary GNSS geodetic and geological measurements in Zagreb and its surroundings were carried 
out from 1997 to 2015. They analyzed and compared results of measurements from 2008 to 2015. The measurements confirmed the constant presence of tectonic activity in the wider area around Medvednica [9]. This indicates that earthquakes are possible in the Zagreb area in future.

\section{Proposal}

The previous three examples of the earthquakes (Kraljevo, Drežnica and Skopje) were analyzed by "The method of daily changing the distances between GNSS permanent referent stations". Based on these results we can conclude that this method can help geophysics with other own methods for eventual earthquakes warning in Zagreb. Today in Zagreb there are approximately million inhabitants and it would be very useful to try within CROPOS to establish department for processing and analysis of GNSS measurement data of the referent stations in order to detect the appearance of compression in earth crust. In this case, after one or more days there is a greater chance to expect earthquakes.

That department would be useful and rational organized within the Control Centre of CROPOS system to detect the appearance of compression of the earth crust based on GNSS measurements. With the help of other geophysical methods, it is probably possible to announce the appearance of major devastating earthquake in Zagreb and its surroundings. In this way, the CROPOS network of permanent reference stations would be used by surveyors, seismologists and other geophysicists. By this way so the large invested financial resources were rationally exploited.

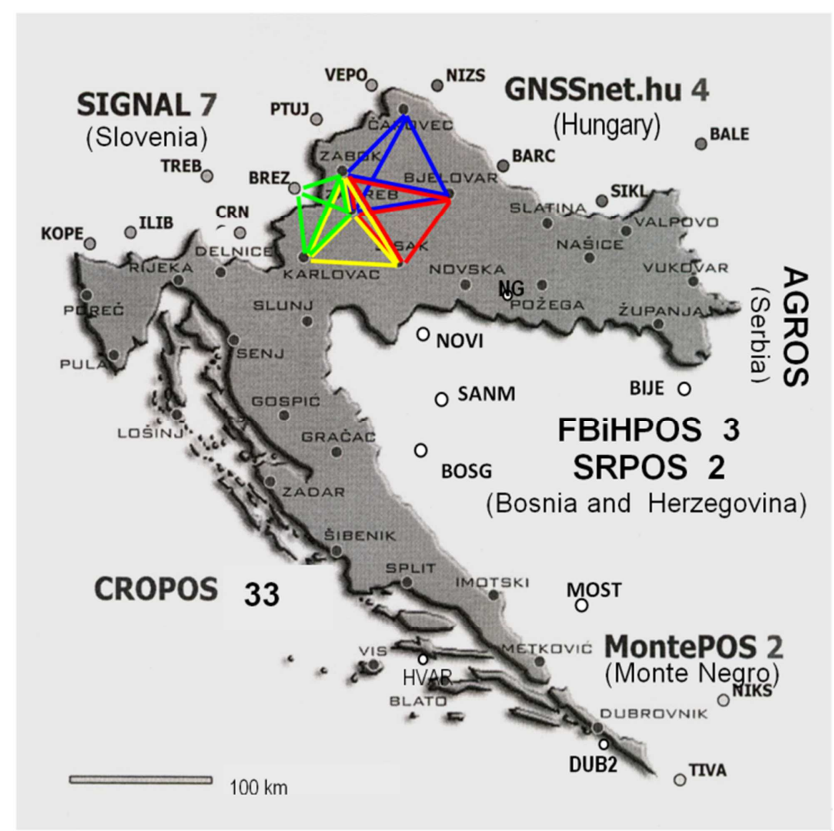

Figure 10. CROPOS Network and three - quadrangles net with diagonal lines and triangle with one GNSS station in triangle for warning the earthquake in Zagreb and surroundings.

In this case, the area of Zagreb should be monitored from daily changes of distances between referent GNSS stations. The first would be analyzed, for example (Figure 10):
1. Blue quadrangle (Zagreb, Zabok, Cakovec, Bjelovar) with diagonals,

2. Red quadrangle (Zagreb, Zabok, Bjelovar, Sisak) with diagonals,

3. Green quadrangle (Zagreb, Karlovac, Brezice, Zabok) with diagonals and

4. Yellow triangle (Sisak, Karlovac, Zabok) with GNSS station Zagreb in this triangle.

The GNSS measurement data of the reference GNSS stations would be used to determine compression in the Earth's crust which precedes the earthquake two or some days later. Also, it will be necessary to predict magnitude of this earthquake especially if it is a devastating earthquake. For this purpose, it will be necessary to have great experience and from largeness of compression tray to predict magnitude of earthquake. By this way we will probably be capable to announce the appearance of devastating earthquakes. It would be necessary to have great experience for evaluation of compression to predict what magnitude will be earthquake. This is important especially if it will be a devastating earthquake greater than about magnitude of 5.0 per Richter. Such a possible earthquake announcement would enable a significant reduction in the number of victims in Zagreb e and reduce the damage.

Today GNSS measurements still have a great perspective of improving accuracy (precision) of positioning. Namely, this can be achieved by installing transmitters on the satellites with the third frequency. Also, the improvement of precision of GNSS measurement is also increased by the increase the number of navigation satellites. [8]. Namely, by introducing new navigation systems Galileo and Beidou and modernizing of existing navigation system GPS and GLONASS. On that way a large number of highly accurate navigation satellites are obtained with the ability to achieve high-precision coordinates of GNSS stations.

For monitoring the area around the Krško nuclear power plant, it is necessary to make detailed analysis together with Slovenian colleagues.

\section{Earthquakes Near Zagreb in 2018}

Seismographs of the Seismological Service of the Republic of Croatia recorded a moderate earthquake with an epicenter ten kilometers south+east of Velika Gorica near Kuce (Figure 11) at 6 hours, 27 minutes, 34.3 seconds on November 24, 2018. The magnitude of the earthquake was 2.7 according to Richter, and in area of epicenter could sense grade III-IV intensities according to the Mercalli-CancaniSieberg (MCS) scale. [18]

Also, the seismographs of the Seismological Service recorded a weak earthquake with the epicenter at Markovo Polje, between Kasina and Sesvete near Zagreb (Figure 11), at 8 hours and 23 minutes on November 26, 2018. The earthquake had a magnitude of $\mathrm{M}=2.4$ according to Richter. Based on magnitude, the intensity at the epicenter of grade III-IV of the Mercalli-Cancani-Sieberg (MCS) scale was calculated. This earthquake was not registered in EMSC 
(European-Mediterranean Seismic Center) but you can see information about this earthquake. [19] In this area in Croatia there were no other registered earthquakes until 8.12.2018 in the EMSC and in Seismological service. [17]

The first, we calculated the daily changes in lengths between GNSS reference stations in the CROPOS network near Zagreb (Figure 11), mostly in the red square of ZabokZagreb, Zabok-Bjelovar, Zagreb-Bjelovar, Zagreb-Sisak, Sisak-Bjelovar, Zabok-Cakovec, Zagreb-Cakovec.

Table 1. Daily changes in lengths between CROPOS GNSS reference stations.

\begin{tabular}{|c|c|c|c|c|c|c|c|}
\hline Date & Zagreb-Cakovec & $\begin{array}{l}\text { Zagreb- } \\
\text { Zabok }\end{array}$ & $\begin{array}{l}\text { Zagreb- } \\
\text { Bjelovar }\end{array}$ & Zagreb-Sisak & $\begin{array}{l}\text { Zabok- } \\
\text { Cakovec }\end{array}$ & $\begin{array}{l}\text { Zabok- } \\
\text { Bjelovar }\end{array}$ & $\begin{array}{l}\text { Bjelovar- } \\
\text { Sisak }\end{array}$ \\
\hline 18.11 .2018 & 1.74 & 0.12 & -0.27 & 0.35 & 1.19 & -0.82 & 0.14 \\
\hline 19.11.2018 & -1.45 & -1.71 & -0.14 & -1.01 & 0.08 & 0.69 & 1.57 \\
\hline 20.11 .2018 & 1.33 & 1.51 & 1.09 & 0.46 & -0.38 & -0.78 & -1.71 \\
\hline 21.11.2018 & 0.73 & 0.76 & 0.35 & 0.16 & 0.20 & 0.30 & 0.86 \\
\hline 22.11 .2018 & -0.88 & -0.72 & -0.13 & 0.49 & -0.20 & -0.14 & 0.17 \\
\hline 23.11 .2018 & 0.41 & -0.31 & -0.37 & 0.34 & 1.00 & 0.22 & -0.33 \\
\hline 25.11 .2018 & 0.85 & -0.05 & 0.15 & -1.14 & 0.12 & -0.90 & 0.03 \\
\hline 26.11 .2018 & -0.82 & 0.56 & -0.38 & 0.26 & -0.83 & 0.41 & -0.14 \\
\hline
\end{tabular}

Earthquakes: 24.11.2018 $\left(\mathrm{M}_{\mathrm{L}}=2.7\right.$ per Richter $)$ and 26.11.2018 $\left(\mathrm{M}_{\mathrm{L}}=2.4\right.$ per Richter $)$.

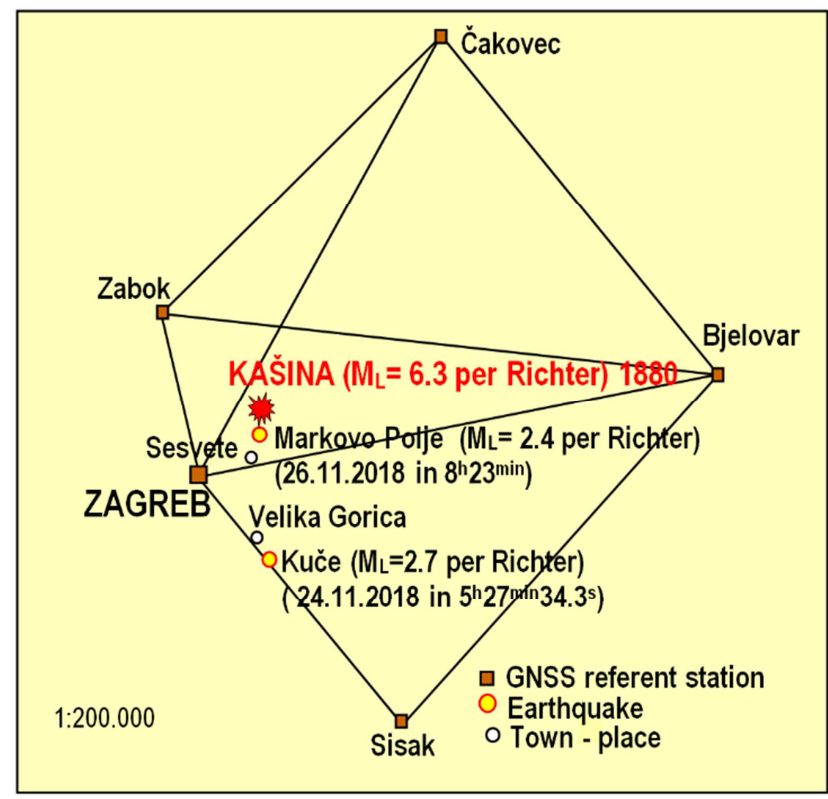

Figure 11. The map of Zagreb with surroundings and epicenters of earthquakes in the 2018, and the epicenter of the largest earthquake in Zagreb in 1880 near Kasina.

Based on the calculated daily length changes between the GNSS reference stations, a graph of the daily length changes (Figure 12) and (Table 1) was made. From it can be seen that there was a compression on 19.11.2018, i.e. shortening side Zagreb-Zabok up to a length of $1.7 \mathrm{~mm} /$ day and sides Zagreb-Cakovec, Zagreb-Bjelovar, Zagreb-Sisak for slightly smaller amounts were reduced. Five days after on the 24 November 2018 was earthquake magnitude 2.7 according to Richter scale in Kuce. The compression of the day 20.11.2019 continued but on other sites, which do not intersect at the same point. So, there is no earthquake behind these compressions. The compression ware on the 22.11.2018 in the 5 sites and after 4 days was earthquake 26.11.2018. in Markovo polje.

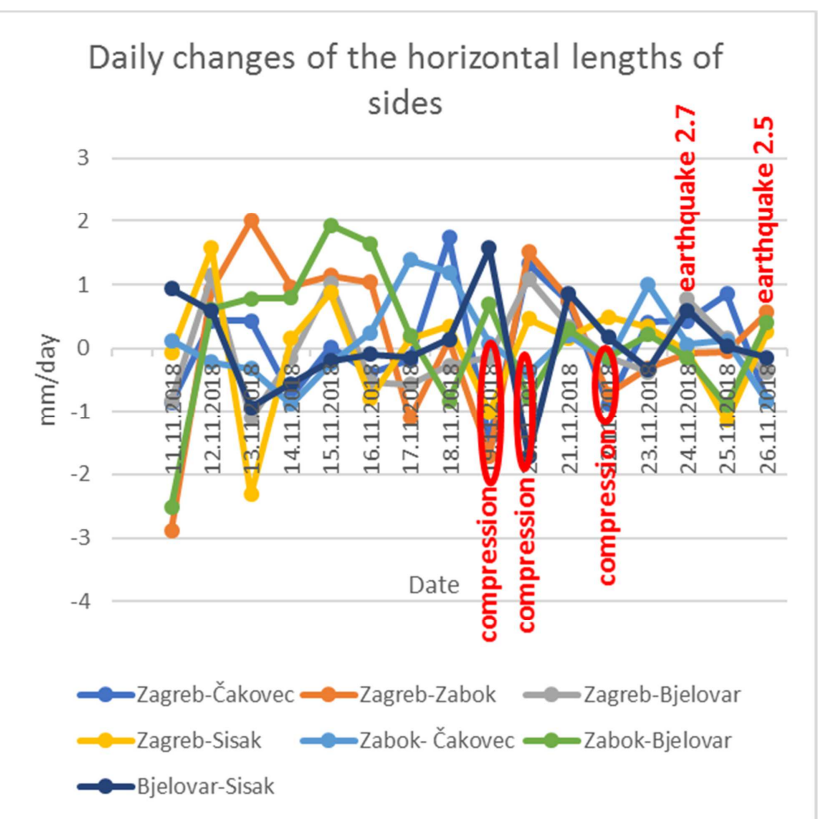

Figure 12. The daily changes in sites length between CROPOS reference GNSS stations.

There was a little less compression 22 November 2018, as there was a slight reduction in some lengths up to $1 \mathrm{~mm} /$ day, and the two sites extended (see Table 1). After the 4 days compression on 26 November 2018 there was a smaller magnitude 2.5 earthquake according to Richter. From this it can be seen that by this method of daily changes the lengths between the GNSS reference stations could also be indicated by earthquakes of small magnitude of 2.5 according to Richter.

\section{Determination Position of Epicenters}

Based on the sides where compression (shortening) occurs, one cannot predict where will be epicenter of earthquake. But it is possible determined area where it will be probably 
occurred. In each case, the point of the epicenter must be

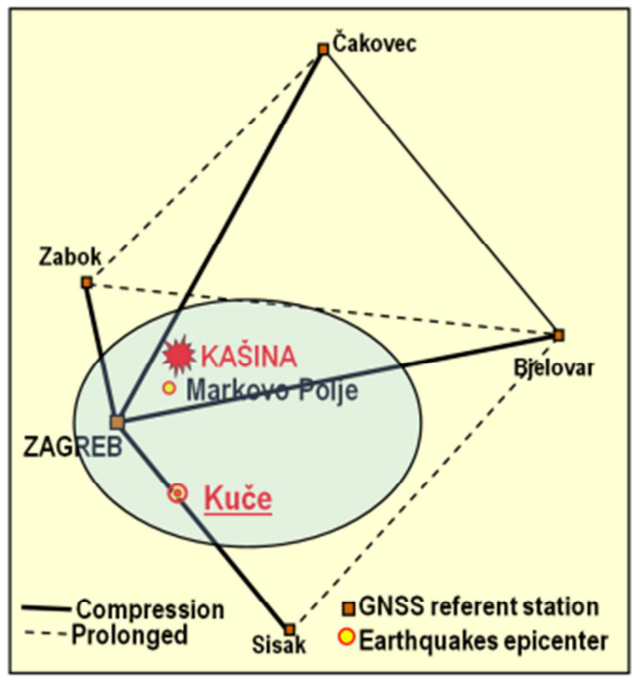

a) between the sides that are compressed i.e. shortened Figure 13.

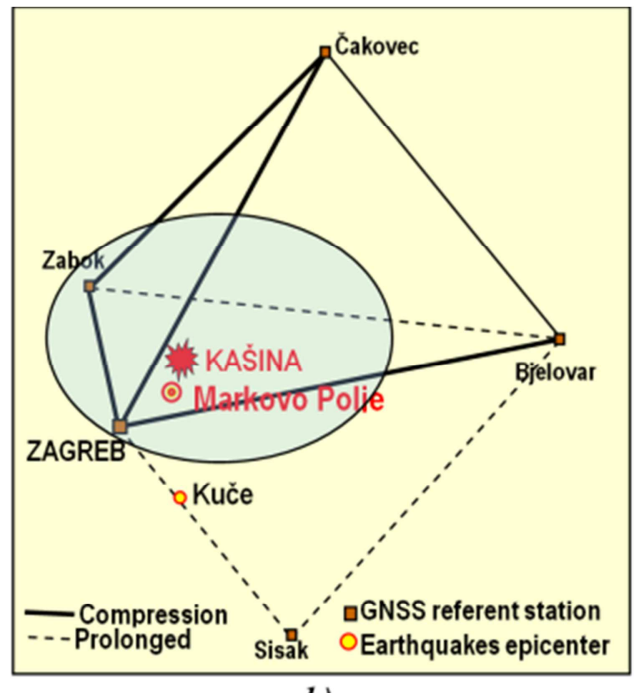

b)

Figure 13. Assessment position of earthquakes epicenters.

\section{Conclusion}

This analysis proves that it makes sense that a part of the service will be organized at the CROPOS Center in Zagreb. It will monitor daily changes of lengths in the Zagreb area between GNSS reference stations and announce ground compressions, after which an earthquake may occur in compressed faults. According to the size of the compression, when it is estimated that this could cause an earthquake of magnitude greater than approximately 5.0 according to Richter, one should consider carefully alerting people to a possible earthquake.

Probably for this purpose big experience will be required.

When it is confirmed that it was proper to organize in Zagreb a part of the service that will monitor the application of lengths between reference stations. Such service should be organized to monitor the lengths around the Krsko Nuclear Power Plant, near Dubrovnik, Split, Rijeka, and wherever necessary.

\section{Acknowledgements}

We are grateful to our colleague's Zeljko and Kristijan Gulija from the company Geowild, representatives of Leica Geosystems from Zagreb, for connecting us with the colleagues from the Agency for Real Estate Cadastre (AREC) in Macedonia. Also, we are very grateful to Dipl. Eng. Saso Dimeski Head of Sector for geodetic works of the AREC in Macedonia, who gave to us the calculated coordinates of the 4 MAKPOS GNSS reference stations around of Skopje but also participated in writing this paper. Thank much to Ph. D. Marko Pavasovic, and mag. sc. Marija Pejakovic for partially assistance in developing this work.

Many thank for useful discussions and helpful advice to Prof. Ph. D. Eduard Prelogovic and Prof. Ph. D. Marijan Herak.

\section{References}

[1] Dalovic S., Skrnjug J. (2011): Analiza promjena dužina baznih linija permanentnih stanica pre i nakon zemljotresa $u$ Kraljevu (Analysis of changes length of the base lines of permanent stations before and after the earthquake in Kraljevo), Geodetska sluzba, 114, 12-19, (Serbia).

[2] Kuk V., Prelogovic E., Sovic I., Kuk K., Sariri K. (2000): Seizmoloske i Seizmotektonske znacajke zagrebackog podrucja (Seismological and seism-tectonically properties of the wider Zagreb area), Gradevinar 52, 11, 647-653 (Croatia). JCE-52-2000-11-02 Rasjedi u okolici Zagreba.pdf (Accessed 4 November 2018).

[3] Marjanovic M., Basic T. (2010): CROPOS - Positioning Easier than Ever, Trimble Dimensions 2010 Conference Converge, Connect and Collaborate, 8-10 November 2010, Las Vegas, USA.

[4] Miklin Z. (2007): Potresi na zagrebackom podrucju (Earthquakes in the Zagreb area) (Kuk V. 2007), http://www.hgi-cgs.hr/zagreb_potresi.html (Accessed 4 November 2018)

[5] Oluic M. (GEOSAT Ltd, Croatia) (2015a): Remote Sensing in Pre-earthquakes Exploration, Case Study of Zagreb Region, Universal Journal of Geosciences 3 (6): 195-197. http://www.hrpub.org DOI: 10.13189/ujg.2015.030603 (Accessed 4 November 2018).

[6] Oluic M. (2015b): Potresi uzroci nastanka i posljedice s posebnim osvrtom na Hrvatsku i s posebnim osvrtom na Hrvatsku i susjedna podrucja (Earthquakes, the causes and consequences with special attention to Croatia and neighboring areas), izdavac (publisher) Prosvjeta- Zagreb (Croatia).

[7] Pavasovic M., Marjanovic M., Basic T. (2015): CROPOS kao Hrvatski terestricki Referentni okvir (CROPOS as Croatian Terrestrial Reference Frame), Proceedings, 4th CROPOS Conference, 22 May 2015, 26-29, Zagreb, Croatia. 
[8] Premuzic M., Sugar D., Bacic Z. (2018): Mogucnosti pozicioniranja primjenom Sustava Galileo i novih metoda mrežnog rjesenja (Positioning possibilities through the application of Galileo system and network positioning methods), 5. CROPOS konferencija - Zbornika radova, Zagreb, studeni 2018, 55-68. http://www.cropos.hr/files/docs/5konferencija/Zbornik_radova.pdf (Accessed 4 November 2018).

[9] Pribicevic B., Dapo A., (2016): Analiza pomaka na Geodinamickoj mrezi Grada Zagreba iz razlicitih vremenskih epoha, (Shift analysis on the City Geodynamic Network of Zagreb from different epochs), Geodetski list, 70 (93), 3, 207 $-230$ (Croatia). https://hrcak.srce.hr/index.php?show=clanak\&id_clanak jezik $=249933$ (Accessed 4 November 2018). http://www.hgicgs.hr/zagreb potresi.html (Accessed 4 November 2018).

[10] Rudeš T. (2010): Zagreb 6, 5 po Richteru - četvrtina grada bila bi sravnjena sa zemljom, (Zagreb 6.5 per Richter - a quarter of a city would be dumped with the earth) Jutarnji list 13.03.2010. https://www.jutarnji.hr/.../zagreb-65-po-richterucetvrtina-grada-bila-bi-sravnjena-sa-z. (Accessed 4 November 2018).

[11] Solaric N., Solaric M., Svehla D. (2012a): Nove revolucionarne mogusnosti u geodeziji koje pruzaju otkrica za koja su dobivene Nobelove nagrade za fiziku 2005. i 1997. godine (New revolutionary opportunities in geodesy that provide the discoveries for which the 2005 and 1997 Nobel Prizes in Physics were awarded) Geodetski list Vol. 66 (92), 1, $1-19$ https://hrcak.srce.hr/index.php?show=toc\&id_broj=7007.

[12] Solaric N., Solaric M. (2012b): Prijedlog da se u Zagrebu i okolici uz CROPOS-ove stanice postavi nekoliko GPS (GNSS) permanentnih stanica za geodinamiku i mogucu najavu veceg zemljotresa $\mathrm{u}$ slijedecem periodu vremena (Proposal for Zagreb and Surroundings a few GNSS permanent stations for geodynamics and possibility the announcement of larger earthquake in the future period), Geodetski list, Vol. 66 (92, 149-164 (Croatia). http://hrcak.srce.hr/95827 (Accessed 4 November 2018).
[13] Solaric N., Solaric M., Pejakovic M. (2017): Dva dana prije potresa u Dreznici 2013. godine doslo je do kompresije terena (Two days before the Earthquake in Dreznica 2013 there has been compression of terrain), Geodetski list, Vol. 71 (94), No. 3, 203-214. (Croatia) https://hrcak.srce.hr/index.php?show=clanak\&id_clanak_jezik $=279500$ (Accessed 4 November 2018).

[14] Solaric N., Solaric M., Bogdanovski Z., Dimeski S. (2018): Three days before the Earthquake in Skopje there was a compression of the Earth's crust, Geodetski list, Vol. 72 (95), No. 1, 15-35 (2018), https://hrcak.srce.hr/200222 (Accessed 4 November).

[15] URL 1: Stanovnici Dreznice o potresu: Tutnjalo je kao da dolazi vlak" (Residents of Dreznica about the earthquake: Has roared as if comes the train"), http://www.24sata.hr/news/graani-zovu-112-tresli-sesjeverno-primorje-i-zagreb326069, (Accessed 4 November 2018).

[16] URL 2: U zemljotresu u Makedoniji oko 50 povrijedenih, građani u panici (In the Earthquake in Macedonia about 50 injured, citizens in panic), https://www.klix.ba/vijesti/regija/uzemljotresu-u-makedoniji-oko-50-povrijedjenih- gradjani-upanici/ 160911075, (Accessed 4 December 2018).

[17] URL 3: Seizmoloska sluzba: Izvjesca o potresima (Seismological Service: Earthquake Reports) (Accessed 4 December 2018).

[18] URL 4: Potres magnitude 2, 7 prema Richteru zatresao je jutros podrucje Velike Gorice, a osjetili su ga i Zagrepcani (A magnitude of 2.7 earthquake according to Richter shook this morning Velika Gorica, and was felt by the people of Zagreb.) https://www.google.hr/search?source=hp\&ei=o5BtXefHa orgT1j6 ACQ\&q=Potres+magnitude $+2 \% 2 \mathrm{C} 7+$ prema+Ri chteru+zatresao+je+ jutros+područje+Velike++Gorice $\% 2 \mathrm{C}$ (Accessed 4 December 2018).

[19] URL 5: Ponovno potres kod Zagreba (Earthquake near Zagreb again) http://hr.n1 info.com/Vijesti/a350548/Potres-kodZagreba.html (Accessed 4 December 2018). 